\title{
Pengaruh Bahan Pengisi (Filler) Eceng Gondok dan Sekam Padi Pada Material Isolasi Listrik (Polymer Epoxy)
}

\author{
Trisna Amelia Fitriah ${ }^{* 1}$, Salama Manjang ${ }^{1}$, Ikhlas Kitta ${ }^{1}$ \\ ${ }^{1}$ Departemen Teknik Elektro, Fakultas Teknik, Universitas Hasanuddin \\ Jl. Poros Malino km.6, Bontomarannu, Gowa, Sulawesi Selatan, Indonesia, 92171 \\ *Email: ameliafitriah26@yahoo.co.id
}

DOI: $10.25042 / j p e .052017 .14$

\begin{abstract}
Abstrak
Penggunaan serat alam sebagai filler dalam bidang industri masih terus dikembangkan, mengingat sifatnya yang ramah lingkungan dan mengandung material yang besar. Penelitian ini dilakukan untuk mengetahui pengaruh eceng godok dan sekam padi sebagai filler pada material resin epoxy. Pembuatan spesimen menggunakan metode hand lay-up dengan masing-masing variasi filler $10 \%-40 \%$ dari berat total bahan uji dan spesimen tanpa filler $0 \%$ sebagai pembanding. Bahan polimer yang digunakan yaitu resin epoxy. Pengujian yang dilakukan yaitu uji tarik,uji resistivitas permukaan dan resistivitas volume. Uji tarik dilakukan menggunakan standar ASTM D-638 dan uji resistivitas menggunakan standar ASTM D 257. Hasil pengujian menunjukkan bahwa nilai resistivitas volume maksimum dicapai dalam kadar eceng gondok $20 \%$ sedangkan pada sekam padi peningkatan resistivitas volume terus terjadi sampai kadar $40 \%$ dari resin epoxy. Peningkatan resistivitas permukaan berlanjut hingga kadar eceng gondok mencapai $20 \%$ pada resin epoxy begitupun dengan penambahan filler sekam padi. Kekuatan tarik dari material resin epoxy mengalami penurunan dengan penambahan eceng gondok dan sekam padi. Nilai kekuatan tarik maksimum dicapai pada komposisi filler $20 \%$. Dengan bertambahnya kadar eceng gondok dan sekam padi didalam resin epoxy, sifat getas dari material resin epoxy semakin meningkat atau terjadi peningkatan kekerasan dari resin epoxy sehingga mengakibatkan kerapuhan
\end{abstract}

\begin{abstract}
The Effect of Boiled Water and Rice Husk as Filler on Electrical Isolation Material (Polymer Epoxy). The use of natural fibers as a filler in the industry still continue to be developed, given its eco-friendly and contains material which is great. This research was conducted to find out the influence of boiled water and rice husk as filler material in epoxy resins. The making of the specimen using the method of hand lay-up with each variation of filler $10 \%-40 \%$ of the total weight of material test and the specimen without filler $0 \%$ for contrast. Polymer materials used i.e. epoxy resins. Testing is done namely pull-test, test volume resistivity and surface resistivity. Pull-test is performed using standard ASTM D-638 and resistivity test using standard ASTM D 257. The test results showed that the maximum volume resistivity values reached in the levels of water hyacinth $20 \%$ whereas on rice husk volume resistivity increase continues to occur until levels of $40 \%$ of the epoxy resins. Surface resistivity continues to increase in the levels of water hyacinth reaches $20 \%$ on epoxy resins as well as the addition of a filler rice husk. The tensile strength of the epoxy resins materials has decreased with the addition of water hyacinth and rice husk. The value of the maximum attainable tensile strength on the composition of the filler is $20 \%$. With increasing levels of water hyacinth and rice husk in epoxy resins, the nature of the material brittle epoxy resins increase or an increase in the hardness of epoxy resin resulting in fragility.
\end{abstract}

Kata-kunci: Eceng gondok, Filler, karakteristik mekanis dan elektrik sekam padi, resin epoxy

\section{Pendahuluan}

Perkembangan industri dengan adanya kemajuan teknologi telah memberikan sumbangan besar terhadap perekonomian Indonesia. Di lain pihak hal tersebut juga memberi dampak pada lingkungan akibat limbah industri maupun eksploitasi sumber daya yang semakin intensif dalam pengembangan industri. Efisiensi bahan dan energi dalam pemanfaatan, pemrosesan dan daur ulang akan menghasilkan keunggulan kompetitif dan manfaat ekonomi. Permasalahan lingkungan yang harus diperhatikan salah satunya adalah pencemaran pada permukaan air. Eutrofikasi merupakan salah satu penyebab pencemaran tersebut, Eutrofikasi adalah pencemaran air yang disebabkan oleh munculnya nutrient yang berlebihan ke dalam ekosistem air. Berdasarkan hal di atas pengembangan industri harus dibarengi dengan 
upaya pengelolaan lingkungan dalam bentuk penanganan limbah yang dilepaskan atau dengan cara mencari bahan baku industri yang ramah lingkungan sebagai bahan alternatif.

Bahan baku eceng gondok (Eichornia crassipes) dan sekam padi merupakan bahan alternatif pilihan untuk isolasi tegangan tinggi . Eceng gondok merupakan jenis tumbuhan air yang memiliki laju pertumbuhan tinggi, sehingga dianggap sebagai gulma yang dapat mengganggu ekosistem perairan [1]. Permasalahan yang timbul dari tingginya populasi eceng gondok adalah berkurangnya jumlah keanekaragaman hewan air, terjadinya pendangkalan, menurunnya kualitas air karena berkurangnya oksigen akibat menurunnya intensitas cahaya matahari yang masuk ke badan air, meningkatnya vector penyakit, gangguan irigasi, transportasi, dan berkurangnya nilai estetika pada perairan $[1,2]$. Eceng gondok diketahui memiliki kandungan lignoselulosa yang tinggi. lignoselulosa terdiri dari lignin,selulosa dan hemiselulosa. Sekam padi memiliki kandungan 24,3\% hemiselulosa, 34,4\% selulosa, dan 19,2\% lignin [3].

Salah satu contoh polimer yang dapat digunakan sebagai bahan dasar isolator pasangan luar dalam bidang ketenagalistrikan adalah resin epoksi. Bahan resin epoxy memiliki beberapa kelebihan antara lain : cairan epoxy memiiki sifat kekentalan yang rendah sehingga mudah bercampur (masuk tahap termoset) didalam pembuatannya,tetapi resin epoksi mempunyai kombinasi antara lain : Sifat kekentalan rendah, mudah dibentuk, penyusutan rendah, kerekatan tinggi, sifat mekanis tinggi, isolasi listrik yang tinggi, ketahanan kimia baik [4].

Selulosa dan lignin merupakan salah satu kriteria yang menunjukkan kekuatan serat. Selulosa merupakan penyusun utama dinding sel dan termasuk polimer glukosa dengan ikatan $\beta$ 1,4 glukosida dalam rantai panjang lurus. Rantai selulosa terhubung dengan ikatan hidrogen dan gaya van der walls [5]. Lignin merupakan komponen yang sangat sulit didegradasi. Komposisi lignin terdiri dari polimer aromatik yang unitnya dihubungkan oleh ikatan eter dan karbon-karbon. Fungsi utama lignin pada tumbuhan adalah memperkuat struktur tumbuhan [6].

Lignoselulosa juga terkandung dalam limbah agrikultural, salah satunya adalah sekam padi. Ketika sekam padi dibakar kadar abu yang diperoleh adalah 17-26\%, jauh lebih tinggi daripada bahan bakar lainnya (kayu 0,2-2\%, batu bara $12,2 \%)$. Sekam padi memiliki nilai kalori tinggi rata-rata dari $3410 \mathrm{kkal} / \mathrm{kg}$ dan dapat digunakan sebagai salah satu sumber energi terbarukan [7]. Sekam padi merupakan residu agrikultural yang ketersediaannya sangat melimpah dan dapat memproduksi bioetanol karena mengandung struktur lignoselulosa.

Sekam padi pada umumnya hanya digunakan sebagai bahan bakar utama atau tambahan pada industri pembuatan bata, media penyemai bibit tanaman, sedangkan abunya sebagian kecil untuk abu gosok dan lainnya dibuang begitu saja. Padahal, apabila abu sekam padi dipanaskan diatas temperatur $500^{\circ} \mathrm{C}$ dengan waktu 105 menit atau lebih akan memberikan kandungan silika amorf optimum sedikitnya $86 \%$ [8]. Penggunaan abu sekam padi sebesar $15 \%$ berat semen akan memberikan peningkatan kuat tekan beton sedikitnya 20\%. Kaitannya dengan ketenagalistrikan silika biasanya digunakan sebagai bahan pengisi dalam pembuatan isolator tegangan tinggi. Mengingat tingginya kandungan silika dalam abu sekam padi maka dilakukan suatu upaya untuk memanfaatkan abu sekam padi sebagai bahan dalam pembuatan nano material $\left(\mathrm{SiO}_{2}\right)$ yang akan digunakan sebagai bahan pengisi (filler) pembuatan nano komposit. Berdasarkan uraian tersebut, dapat disimpulkan bahwa selulosa dan silika dari sekam padi dapat manfaatkan sebagai filler .

Isolator sebagai salah satu peralatan listrik memegang peranan penting dalam proses penyaluran energi listrik. Isolator pemasangan luar yang populer dikembangkan saat ini adalah isolator berbahan polimer, dikarenakan bahan polimer mempunyai banyak kelebihan dibandingkan bahan porselin dan gelas. Di antaranya adalah mempunyai sifat hidrofobik yang tinggi, mempunyai rapat massa yang lebih rendah, mudah dibuat karena tidak memerlukan suhu yang sangat tinggi dalam proses 
pembuatannya, dan mempunyai tingkat kerekatan yang tinggi [9].

Selain kelebihan yang dimiliki oleh resin epoksi terdapat pula beberapa kelemahan yaitu, Mudah mengalami proses penuaan (aging) dan degradasi pada permukaan akibat adanya stress listrik dan termal. Kinerja sifat tolak airnya rendah, sangat sensitif jika digunakan didaerah yang bersuhu tinggi, berkelembaban tinggi, dan adanya radiasi UV dengan intensitas tinggi yang akan menurunkan kinerjanya [10]. Untuk meningkatkan kinerja resin epoksi sehingga dapat digunakan dalam aplikasi luar ruangan, penyediaan aditif seperti filler ditambahkan.

Adapun jenis filler yang akan digunakan pada resin epoksi adalah Silika dan selulosa. Silika memiliki kekuatan mekanik yang tinggi dan memiliki daya tahan yang tinggi terhadap bahan dan serat. Silika dan serat dapat meningkatkan karakteristik mekanik dan elektrik dari resin epoxy. Dengan pemanfaatan eceng gondok dan sekam padi ini diharapkan mampu mengurangi biaya produksi dengan kualitas mekanik dan listrik yang baik, disamping dapat mengoptimalkan pengendalian gulma serta mengurangi limbah dari sekam padi.

\section{Bahan dan Metode Analisa}

\subsection{Resin Epoxy}

Material yang digunakan dalam penelitian ini adalah Lem epoxy dengan type RTV (Room Temperature Vulcanization) atau mengeras dalam suhu ruang. Resin epoxy diperoleh dari PT. AVIA AVIAN, adapun merek dagangnya adalah avian 2 komponen yang terdiri dari 2 bagian yaitu resin dan hardener.

\subsection{Eceng Gondok}

Eceng gondok yang dimaksud disini adalah Eceng gondok dengan bahasa latin Eichornia Crassipes diperoleh dari perairan kota makassar. Sebelum di haluskan, tanaman tersebut di cuci bersih dan diambil daunnya untuk dikeringkan
Tabel 1. Hasil pengujian ligniselulosa pada eceng gondok

\begin{tabular}{ccc}
\hline No & $\begin{array}{c}\text { Nama } \\
\text { Senyawa }\end{array}$ & $\begin{array}{c}\text { Persentase } \\
(\mathbf{\%})\end{array}$ \\
\hline 1 & Lignin & 3,97 \\
\hline 2 & Selulosa & 23,54 \\
\hline 3 & Hemiselulosa & 28,19 \\
\hline
\end{tabular}

\subsection{Sekam Padi}

Sekam padi diperoleh dari kabupaten Sidrap yang telah di panaskan diatas $500{ }^{\circ} \mathrm{C}$.

Tabel 2. Hasil pengujian komposisi kimia pada sekam padi

\begin{tabular}{ccc}
\hline No & $\begin{array}{c}\text { Nama } \\
\text { Senyawa }\end{array}$ & $\begin{array}{c}\text { Persentase } \\
(\%)\end{array}$ \\
\hline 1 & $\mathrm{SiO}_{2}$ & 97,99 \\
\hline 2 & $\mathrm{P}_{2} \mathrm{O}_{5}$ & 0,50 \\
\hline 3 & $\mathrm{CaO}$ & 0,496 \\
\hline 4 & $\mathrm{~K}_{2} \mathrm{O}$ & 0,491 \\
\hline 5 & $\mathrm{MnO}$ & 0,268 \\
\hline 6 & $\mathrm{Cl}$ & 0,179 \\
\hline 7 & $\mathrm{Fe}_{2} \mathrm{O}_{3}$ & 0,038 \\
\hline 8 & $\mathrm{ZnO}$ & 0,0124 \\
\hline 9 & $\mathrm{Rb} 2 \mathrm{O}$ & 0,0076 \\
\hline
\end{tabular}

\section{Metode Penelitian}

Pengujian karakteristik material resin epoxy dalam keadaan standar yaitu tanpa perlakuan khusus. Pengujian karakteristik elektris terdiri dari 3 jenis pengujian yaitu, resistivitas permukaan, resistivitas volume dan kekuatan dielektrik. Untuk Pengujian mekanik yaitu pengujian karakteristik kekuatan tarik. Pengujian dilakukan pada beberapa laboratorium dengan menggunakan alat uji yang telah terstandarisasi atau dengan menggunakan metode uji berstandar internasional dimana dalam penelitian ini digunakan standar ASTM. Setelah data-data pengujian diperoleh selanjutnya dilakukan analisa data. Pada tahap ini karakteristik elektris dan mekanis dari material dibuat berdasarkan datadata yang diperoleh dari pengukuran yang telah dilakukan. Karakteristik tersebut kemudian dianalisa mengenai sebab-sebab perubahan karakteristik yang telah didapatkan juga dicari nilai optimum untuk masing-masing jenis pengujian yang telah dilakukan untuk kemudian dijadikan sebagai parameter penentu apakah eceng gondok dan sekam padi layak dijadikan filler untuk material insulasi resin epoxy. 


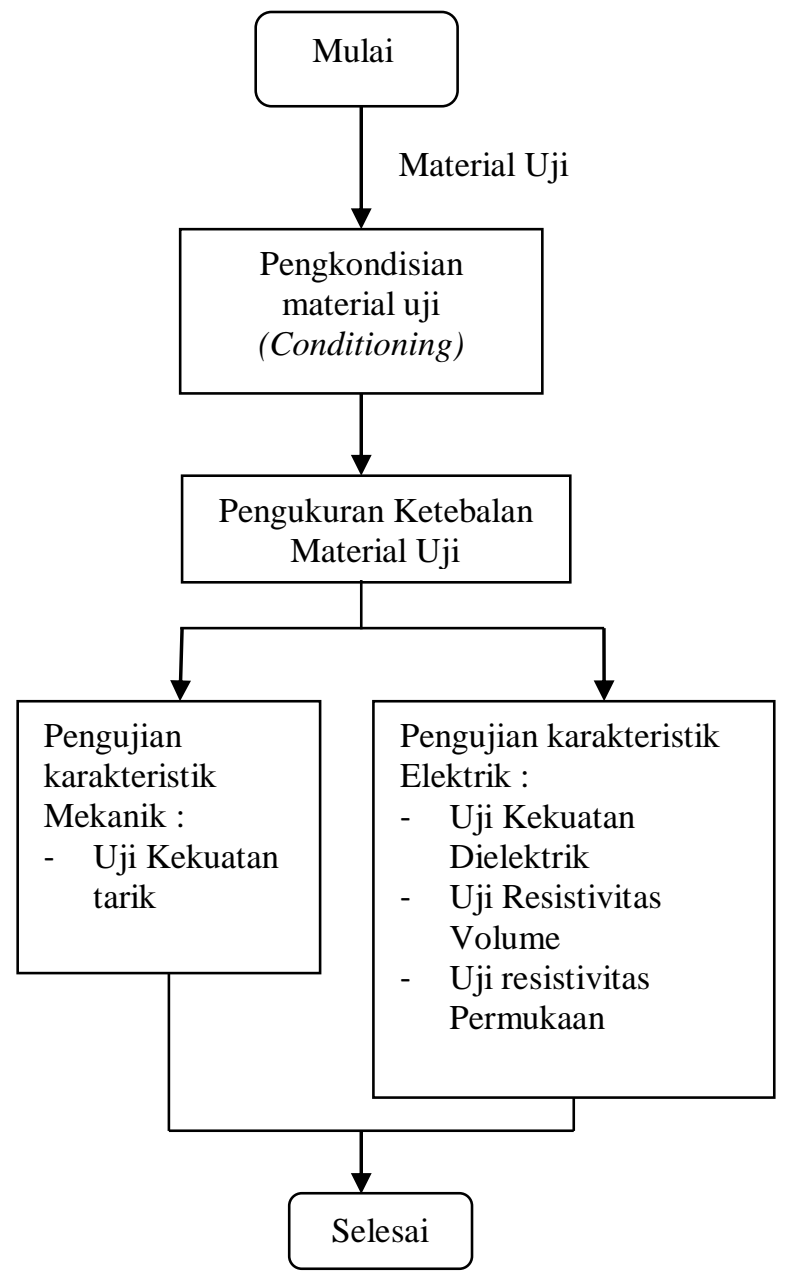

Gambar 1. Diagram alir dari prosedur dan jenis pengujian material uji

\section{Hasil dan Pembahasan}

\subsection{Resistivitas Volume}

Pada Gambar 2 dapat dilihat bahwa penambahan Eceng gondok dalam resin epoxy meningkatkan resistivitas volume dari resin epoxy tersebut hingga pada komposisi filler $20 \%$. Setelah itu penambahan eceng gondok akan membuat resistivitas volume dari material resin epoxy menjadi menurun kemudian tidak linear. Pada komposisi filler $20 \%$ peningkatan resistivitas volume dari material Resin epoxy adalah sekitar $87,68 \%$ dibandingkan dengan material resin epoxy tanpa pemberian filler.

Penambahan sekam padi dalam resin epoxy meningkatkan resistivitas volume dari resin epoxy tersebut hingga pada komposisi filler $40 \%$ tanpa mengalami penurunan. Pada komposisi filler $40 \%$ peningkatan resistivitas volume dari material resin epoxy adalah sekitar 234,384\% dibandingkan dengan material resin epoxy tanpa pemberian filler. Ada beberapa faktor yang dapat mempengaruhi resistivitas volume bahan terutama jika bahan diuji pada tegangan tinggi DC impuls. Mineralogi bahan pengisi, ikatan kimia, distribusi molekul dan banyak faktor kimia lainnya akan memberikan kontribusi pada resistivitas material.

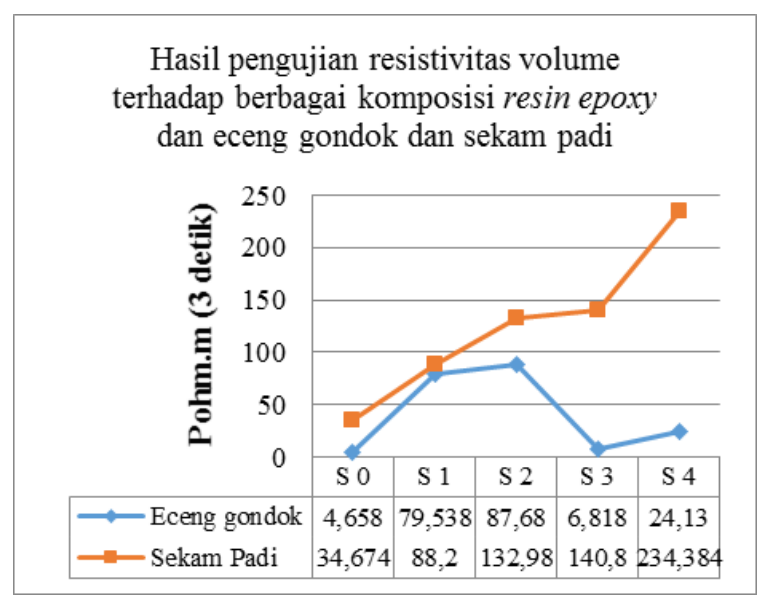

Gambar 2. Pengaruh penambahan Eceng gondok dan sekam padi dalam resin epoxy terhadap resistivitas volume dari material.

\subsection{Resistivitas Permukaan}

Pada Gambar 3 dapat dilihat bahwa dengan penambahan kadar eceng gondok pada resin epoxy, resistivitas permukaan dari material resin epoxy menjadi meningkat. Peningkatan resistivitas permukaan berlanjut hingga kadar eceng gondok mencapai $20 \%$ pada resin epoxy. Penambahan kadar sekam padi pada resin epoxy, resistivitas permukaan dari material resin epoxy mengalami penurunan dibanding resin epoxy tanpa filler. Peningkatan resistivitas permukaan meningkat pada penambahan filler $20 \%$.

Nilai resistansi dari suatu material akan bergantung pada jenis tegangan/medan yang dikenakan pada material tersebut. Pada material dengan kandungan partikel semikonduktif yang tinggi, resistansi dari resin epoxy. Material akan berubah tergantung besar dan jenis tegangan/medan yang diberikan. Pada besar tegangan/kuat medan tertentu yang diberikan pada material, nilai resistansi material dapat berubah hal itu tergantung dari lebar celah pita 
(band gap) antara pita valensi dan konduksi dari senyawa-senyawa penyusun material tersebut.

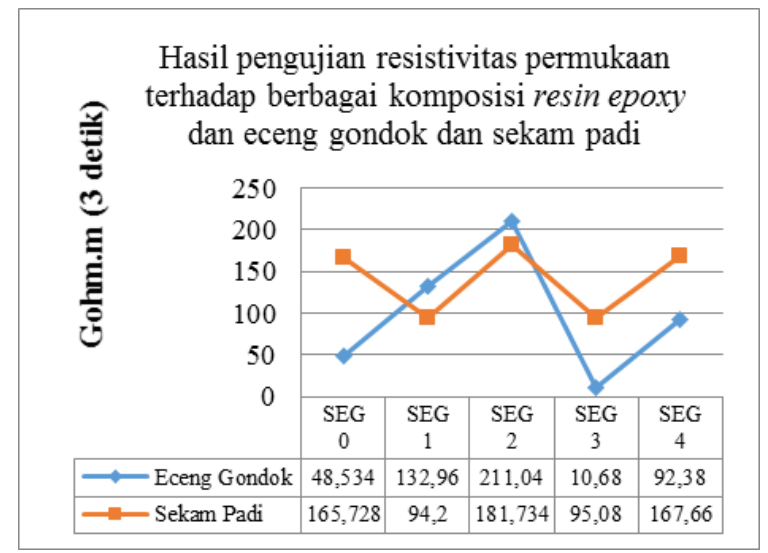

Gambar 3. Pengaruh penambahan eceng gondok dan sekam padi dalam resin epoxy terhadap resistivitas permukaan dari material.

\subsection{Kekuatan Dielektrik}

Penambahan eceng gondok ke dalam resin epoxy akan meningkatkan kekuatan dielektrik dari material resin epoxy. Peningkatan kekuatan dielektrik maksimum terjadi pada komposisi eceng gondok sebesar $30 \%$ terhadap berat resin epoxy. Peningkatan kekuatan dielektrik maksimum terjadi pada komposisi sekam padi sebesar $10 \%$ terhadap berat resin epoxy dan mengalami penurunan seiring penambahan filler. Tegangan tembus bahan yang diuji dapat dipengaruhi oleh sifat intrinsik dari bahan tersebut dan juga faktor ekstrinsik. Adapun faktor intrinsik yang mempengaruhi tegangan tembus material adalah struktur kimia, ketidakteraturan struktur, kehadiran aditif, pergerakan molekular (zat cair) dan sebagainya.

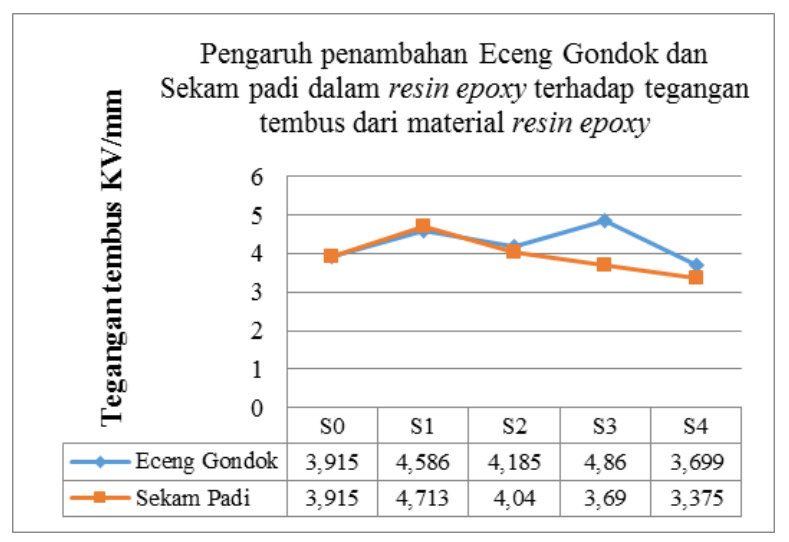

Gambar 4. Pengaruh penambahan eceng gondok dalam resin epoxy terhadap tegangan tembus dari material resin epoxy

\subsection{Kekuatan Tarik}

Penambahan filler eceng gondok dan sekam padi pada resin epoxy menurunkan kekuatan tarik material, hal ini terlihat jika dibandingkan terhadap komposisi resin epoxy tanpa pemberian filler. Kekuatan tarik maksimum dicapai pada komposisi eceng gondok dan sekam padi $20 \%$ yaitu sebesar $1 \mathrm{kgf} / \mathrm{mm}^{2}$. Setelah itu terjadi perubahan kekuatan tarik yang tidak linear pada komposisi diatas 30 dan $40 \%$.

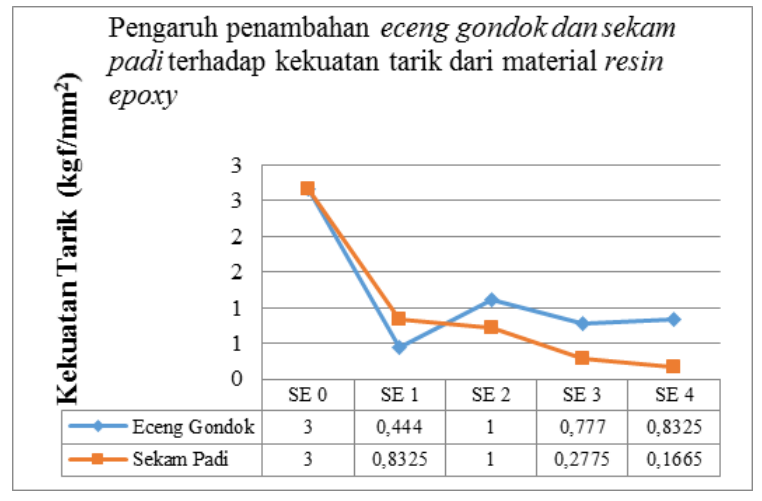

Gambar 5. Pengaruh penambahan eceng gondok dan sekam padi dalam resin epoxy terhadap kekuatan tarik dari material resin epoxy

\section{Kesimpulan}

Berdasarkan hasil penelitian dapat disimpulkan bahwa karakteristik eceng gondok dan sekam padi sebagai filler dalam resin epoxy dapat meningkatkan beberapa parameter elektrik dari material resin epoxy. Peningkatan maksimum karakteristik elektrik dari material resin epoxy seperti kekuatan dielektrik, resistivitas volume dan resistivitas permukaan mengalami peningkatan.

Peningkatan maksimum terjadi pada komposisi filler eceng gondok secara berturut sebesar $30 \%$, $20 \%$ dan $20 \%$ dari material resin epoxy. Peningkatan maksimum terjadi pada komposisi filler sekam padi secara berturut sebesar $10 \%, 20 \%$ dan $20 \%$ dari material resin epoxy. Kekuatan tarik dari material resin epoxy menunjukkan terjadi penurunan kekuatan. Penurunan kekuatan tersebut dapat dilihat dari material resin epoxy dengan penambahan eceng gondok dan sekam padi dibandingkan dengan material tanpa filler. Kekuatan tarik tanpa filler memiliki kekuatan $3 \mathrm{kgf} / \mathrm{mm}^{2}$ setelah dilakukan penambahan filler eceng gondok kekuatan tarik 
menunjukkan $0,444 \mathrm{kgf} / \mathrm{mm}^{2}, 1 \mathrm{kgf} / \mathrm{mm}^{2}, 0,777$ $\mathrm{kgf} / \mathrm{mm}^{2}, 0,8325 \mathrm{kgf} / \mathrm{mm}^{2}$. Penambahan filler sekam padi kekuatan tarik menunjukkan 0,8325 $\mathrm{kgf} / \mathrm{mm}^{2}, 1 \mathrm{kgf} / \mathrm{mm}^{2}, 0,2775 \mathrm{kgf} / \mathrm{mm}^{2}, 0,1665$ $\mathrm{kgf} / \mathrm{mm}^{2}$. Hal ini disebabkan kurangnya homogenitas bahan padat yang diuji.

\section{Referensi}

[1] Cheng, J, Xie, B., Zhou, J., Song, W., dan Cen, K. (2008). Cogeneration of $\mathrm{H} 2$ and CHfrom Water Hyacinth by Two-Step Anaerobic Fermentation. International Journal of Hydrogen Energy 35, 30293025.

[2] Gunnarson, C. G. dan Peterson, C. M. (2007). Water Hyacinth as aResource and Energy Production: a Literature Review. Journal of Waste Management 27, 117-129.

[3] Soltani, N., Bahrami, A., Pech-Ganul, M. I., dan Gonzalez, L. A. (2015). Review on the Physicochemical Treatments of Rice Husk for Production of Advanced Materials. Chemical Engineering Journal 264, 899-935.

[4] Prasojo, Winarko Ari, Abdul Syakur, dan Yuningtyastuti, Analisis Partial Discharge pada Material Polimer Resin Epoksi dengan Menggunakan Elektroda Jarum Bidang, Penelitian, Universitas Diponegoro, Semarang, 2009.

[5] Perez, J., Dorado, J. M., Rubia, T., dan Martinez, J. (2002). Biodegradation and Biological
Treatments of Cellulose, Hemicellulose, and Lignin: An Overview. Int. Microbiol 5, 53-63.

[6] Girisuta,B.(2007). Levulinic Acid from Lignocellulosic Biomass.Proefshrift University of Gronigen.

[7] Andy Chandra, S.T., M.M. 2012. Isolasi Dan Karakterisasi Silika Dari Sekam Padi. Lembaga Penelitian dan Pengabdian kepada Masyarakat Universitas Katolik.

[8] Hasyim Asy'ari (2008) "The Effect Of Industrial Pollutionto The Mechanical Performance Of Epoxy Resin Insulation Material Using Silicone Rubber and Rice Husk Ash As Filler'. Jurnal Penelitian Sains \& Teknologi, 9(1): 94-106.

[9] Manjang, Salama, and Masayuki Nagao. "Characteristics of high voltage polymer insulator under accelerated artificial tropical climate multi stress aging." Electrical Insulating Materials (ISEIM), Proceedings of 2011 International Conference on. IEEE, 2011.

[10]Kitta, Ikhlas.2015.Seminar Nasional Teknik Energi dan Ketenagalistrikan SNTEK 2015 Pengaruh Fly Ash Batubara Terhadap Perilaku Hydrophobicyty Isolator Polimer. 